\title{
Light Absorption and Carotenoid Synthesis of Pot Marigold (Calendula officinalis L.) in Response to Phosphorous and Potassium Varying Levels
}

\author{
Mohammad SEDGHI', Alireza PIRZAD², Bahman AMANPOUR-BALANEJI ${ }^{3}$ \\ ${ }^{1}$ University of Mohaghegh, Faculty of Agriculture, Department of Agronomy and Plant Breeding; mosedghi2003@yahoo.com \\ ${ }^{2}$ University of Urmia, Faculty of Agriculture, Department of Agronomy and Plant Breeding, Urmia, Iran; pirzadalireza@gmail.com \\ ${ }^{3}$ Young Researchers Club of Islamic Azad University, Urmia branch,Urmia, Iran; amanpour.b@gmail.com
}

\begin{abstract}
In order to provide additional information on the effects of elemental deficiency on factors that affect plant production in medicinal plants, a factorial field experiment as randomized complete block design was conducted on Calendula officinalis. Treatments were four phosphorus levels $\left(\mathrm{P}_{2} \mathrm{O}_{5}\right)$ including $0,40,80$ and $120 \mathrm{Kg} \mathrm{ha}^{-1}$ and four potassium levels $\left(\mathrm{K}_{2} \mathrm{O}\right)$ as 0, 50, 100 and $150 \mathrm{Kg} \mathrm{ha}^{-1}$. Results showed that applied treatments had significant effects on petal carotenoids and the highest amount of $\beta$ - carotene obtained at 80 and $150 \mathrm{Kg} \mathrm{ha}^{-1} \mathrm{P}_{2} \mathrm{O}_{5}$ and $\mathrm{K}_{2} \mathrm{O}$, respectively. Effect of $\mathrm{K}_{2} \mathrm{O}$ on light interception and light use efficiency was significant and the highest radiation use efficiency achieved by applying $150 \mathrm{Kg} \mathrm{ha}^{-1} \mathrm{~K} \mathrm{O}$. The highest yield of grain and dry flowers was recorded in the mixture of 80 and $150 \mathrm{Kg} \mathrm{ha}^{-1} \mathrm{P}_{2} \mathrm{O}_{5}$ and $\mathrm{K}_{2} \mathrm{O}$, respectively. In conclusion, using of $\mathrm{K}_{2} \mathrm{O}$ had greater effects on studied traits than $\mathrm{P}_{2} \mathrm{O}_{5}$.
\end{abstract}

Keywords: carotenoids, light extinction coefficient, light interception efficiency, pot marigold

\section{Introduction}

Calendula officinalis (pot Marigold), belongs to Asteraceae family, is an annual herb with yellow to orange flowers, native to Mediterranean region (Gazim et al., 2008). Pot Marigold is cultivated for its flowers with receptacle or flowers without receptacle (Varban et al., 2008) which are used as the medical raw material. The flower contains essential oils which are used for high blood-fat and treatment of inflammation intestine organs (Mrda et al., 2007). It strengthens the organism immunity. Active ingredient contents reported previously for $C$. officinalis flowers are: flavonoids, carotenoids, ethereal oils, triterpenic saponosins, calenduloside, phytoncids, tannins, resins, slime, glycosides, C vitamin and organic acids (Mrda et al., 2007).

Cultivation of medical plants has advantages in relation to assembling the medical plants from the nature. There is the production of the pure, flat rate and quality medical raw material. It can be accomplished by choosing the right plant species, right cultivars, soil, with the appropriate practical measures, with the optimal sowing date, the right plant nutrition, harvest, drying and etc. There are more advantages, like the high yield, possibility of the professionally supervision, obtaining the quality row material without additive and impurity (Mrda et al., 2007).

At the present time, fertilizers are applied to almost every crop that is grown commercially. Most of the studies investigating fertility and plant nutrition have focused on nitrogen, and its requirements as well as it effects in the plants response to increased nitrogen rates are well known (Everet and Subramaya, 1983; Jones et al., 1988). Few studies examining phosphorus and potassium fertility in pot Marigold have been conducted, but they are not specific to the medicinal use of this plant. Potassium is one of the three major essential nutrient elements required by plants. Unlike nitrogen and phosphorus, potassium does not form bonds with carbon or oxygen, so it never becomes a part of protein and other organic compounds (Hoeft et al., 2000). Phosphorus functions cannot be performed by any other nutrient, and an adequate supply of $\mathrm{P}$ is required for optimum growth and reproduction. Phosphorus is classified as a major nutrient, meaning that it is frequently deficient for crop production and is required by crops in relatively large amounts. It is a part of several key plant structure compounds and as catalysis in the conversion of numerous key biochemical reactions in plants. Phosphorus is noted especially for its role in capturing and converting the sun's energy into useful plant compounds. Phosphorus is a vital component of ATP, the "energy unit" of plants. ATP forms during photosynthesis, has phosphorus in its structure, and processes from the beginning of seedling growth through to the formation of grain and maturity. Thus phosphorus is essential for the general health and vigor of all plants. Some specific growth factors that have been associated with phosphorus are: stimulated root development, increased stalk and stem strength, improved flower formation and seed production, more uniform and earlier crop maturity, improvements in crop quality, and increased resistance to plant diseases (Taiz and Zeiger, 2003). 
Vijay et al (2009) investigated the effects of different dosages of NPK fertilizers on growth and constituents of Asparagus racemosus. They found that $\mathrm{P}$ and $\mathrm{K}$ at the highest concentration had the maximum effect on dry matter, carbohydrate, protein and sapogenin increasing in this plant root tubers. They concluded that NPK had the positive effect on photosynthesis and increasing of photosynthates which were stored in root tubers. Mandal et al. (2008) studied the effect of NPK on Isabgol (Plantago ovata) seed yield and leaf phenols. Results showed that only $\mathrm{N}$ and $\mathrm{K}$ had significant effects on leaf phenols, but seed yield only affected by Thomaz et al. (2007) studied the effect of phosphorus and nitrogen amendments on the growth of Egeria najas. They concluded that both $\mathrm{N}$ and $P$ has sharp effects on relative growth rate of this aquatic plant and $\mathrm{N}$ uptake was more crucial than $\mathrm{P}$.

As the combining effect of $\mathrm{P}$ and $\mathrm{K}$ has been rarely studied in the literature especially in pot Marigold and on the base of best of our knowledge there are no reports in this area, an experiment conducted to determine the effects of $\mathrm{P}$ and $\mathrm{K}$ on light use and metabolite production in pot Marigold and invigorative effects of these elements on flower production.

\section{Materials and methods}

Field experiment carried as factorial based on complete block design arrangement with three replications at the research farm of university of Mohaghegh Ardabili, Ardabil, Iran. Seeds of C. officinalis obtained from the Pakan Bazr Company, Isfahan, Iran. Soil analysis result for this region was presented in Tab. 1. Treatments were phosphorus $\left(\mathrm{P}_{2} \mathrm{O}_{5}\right)$ levels as control, 40,80 and $120 \mathrm{~kg} \mathrm{ha}^{-1}$ and potassium fertilizer $\left(\mathrm{K}_{2} \mathrm{O}\right)$ with four levels as control 50, 100 and $150 \mathrm{~kg} \mathrm{ha}^{-1}$.

Radiation intensity at canopy and soil surfaces was measured by Sun Scan instrument (model BF3, Delta-T devices, UK). Leaves area was measured by portable leaf area meter and leaf area index was calculated by the formula below:

$$
\mathrm{LAI}=\mathrm{LA} / \mathrm{S}
$$

That "LA" is the leaves area and " $\mathrm{S}$ " is the ground surface that covered by leaves.

Light interception efficiency (LIE) was calculated with the formula proposed by Board and Harville (1992), as below:

$$
\text { LIE }=\text { LI/LAI }
$$

"LI" is the light interception by canopy that was calculated according to Purcell et al (2002):

$$
\mathrm{LI}=1-\left(\mathrm{I} / \mathrm{I}_{0}\right)
$$

Tab. 1. Physiochemical properties of the soil in experimental field
That " $\mathrm{I}_{0}$ " is the light intensity ( $\mu \mathrm{mol}$ photon $\mathrm{m}^{-2} \mathrm{~min}^{-1}$ ) at the canopy surface and "I" is the light intensity at soil surface.

Light extinction coefficient $(\mathrm{K})$ was calculated based on Lambert- Beer law as fallow:

$$
\mathrm{I} / \mathrm{I}_{0}=\mathrm{e}^{-\mathrm{K}(\mathrm{LAI})}
$$

Which, "e" is the natural logarithm.

Radiation use efficiency (RUE) was calculated as below (Rosenthal et al., 1993):

$$
\mathrm{RUE}=\mathrm{DM} / \mathrm{I}
$$

That, DM is the dry matter of canopy.

Petal cartenoids were measured by gas chromatography (GC) model G890N (Agilent Technologies, USA).

Element absorption affinity $\left(\mathrm{K}_{\mathrm{m}}\right)$ was calculated according to Thomaz et al. (2007) by modified MichaelisMenten equation:

$$
\frac{S}{R G R}=\frac{1}{V_{\max }} \times R G R+\frac{K_{m}}{V_{\max }}
$$

Petal yield was determined at flowering by harvesting the $0.5 \mathrm{~m}^{-2}$ of each plot, and drying at $45^{\circ} \mathrm{C}$ for $24 \mathrm{~h}$.

\section{Statistical analysis}

Collected data was subjected to normality test before analysis of variance (ANOVA). ANOVA procedure was performed by SAS 9.1 and mean comparison was done using Duncan's Multiple Range Test (DMRT).

\section{Results and discussion}

\section{Light Interception Efficiency (LIE)}

Analysis of variance showed that only the simple effect of $\mathrm{K}_{2} \mathrm{O}$ is significant on LIE as shown in Tab. 2. LIE is the amount of light absorbance by specific leaf area that is capable to do work. The higher LIE (0.64) achieved by using $150 \mathrm{~kg} \mathrm{ha}^{-1} \mathrm{~K}_{2} \mathrm{O}$ (Fig. 1).

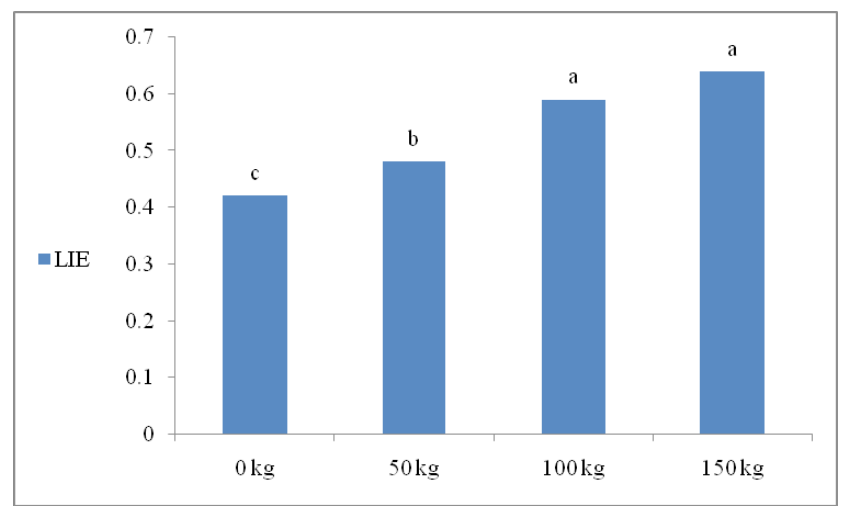

Fig. 1. Effect of different potassium rates on the percentage of light interception efficiency (LIE) in C. officinalis

\begin{tabular}{ccccccccc}
\hline $\begin{array}{c}\text { Salinity } \\
\left(\mathrm{ds} \mathrm{m} \mathrm{m}^{-1}\right)\end{array}$ & $\mathrm{pH}$ & $\begin{array}{c}\text { Saturation } \\
(\%)\end{array}$ & $\begin{array}{c}\text { Lime } \\
(\%)\end{array}$ & Texture & $\begin{array}{c}\text { Carbon } \\
(\%)\end{array}$ & $\begin{array}{c}\text { Nitrogen } \\
(\%)\end{array}$ & $\begin{array}{c}\mathrm{P}_{2} \mathrm{O}_{5} \\
(\mathrm{ppm})\end{array}$ & $\begin{array}{c}\mathrm{K}_{2} \mathrm{O} \\
(\mathrm{ppm})\end{array}$ \\
\hline 3.61 & 8.20 & 46 & 18.06 & silty loam & 1.71 & 0.16 & 20 & 700 \\
\hline
\end{tabular}




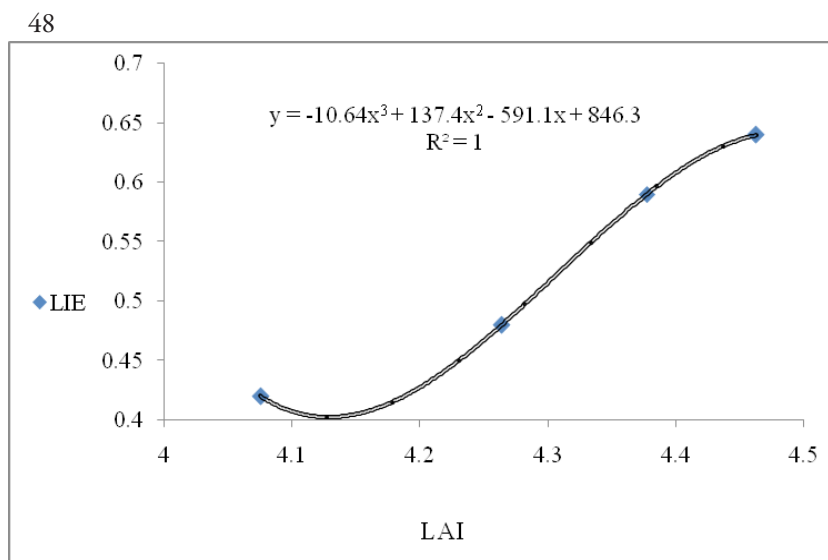

Fig. 2. Regression relation between leaf area index (LAI) and light interception efficiency (LIE) in C. officinalis

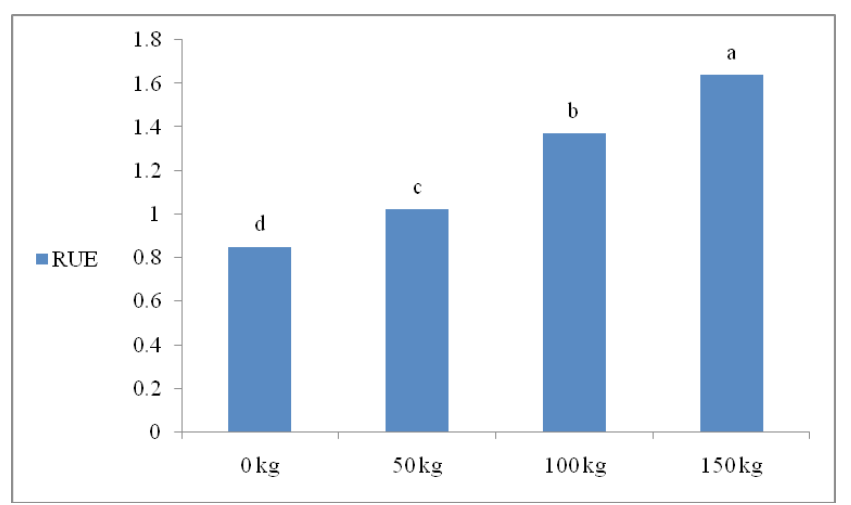

Fig. 3. Effect of different potassium rates on radiation use efficiency (RUE) in C. officinalis

LIE is low just before canopy closure and then will reach to maximum rate. In this point increasing leaf area has negative effect on LIE, because to shading of downer leaves (Fig. 2). There was a negative relation between LAI and LIE, so with increasing LAI, LIE was decreased. Increasing LAI, to about 4.5 did not decrease LIE, but it is expected that in higher LAI than 4.5 , there will be a reduction in LIE.

\section{Radiation use efficiency (RUE)}

Simple effect of $\mathrm{K}_{2} \mathrm{O}$ was significant on RUE (Tab. 2). RUE is the explanatory parameter of dry matter production per intercepted radiation unit (Purcell et al., 2002).

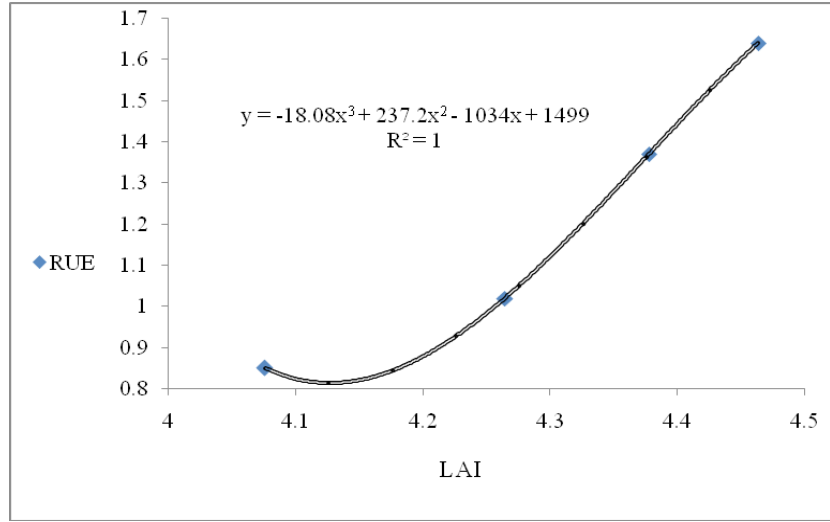

Fig. 4. Regression relation between leaf area index (LAI) and radiation use efficiency (RUE) in C. officinalis

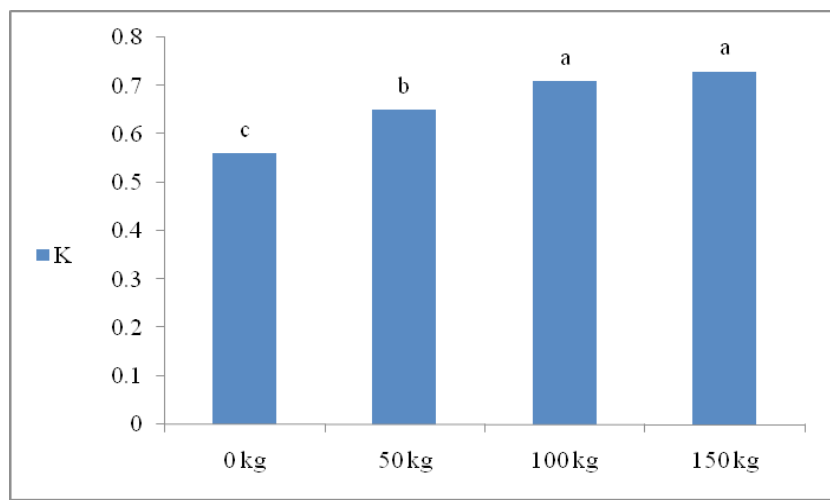

Fig. 5. Effect of different potassium rates on light extinction coefficient $(\mathrm{K})$ in C. officinalis

Comparison of means showed the highest RUE (1.64) by applying $150 \mathrm{~kg} \mathrm{ha}^{-1} \mathrm{~K}_{2} \mathrm{O}$ (Fig. 3). It means that each MJ light energy $\mathrm{m}^{-2}$ can produce $1.64 \mathrm{~g}$ of dry matter. Agele et al. (2007) demonstrated that RUE for many plants is 1.2$1.7 \mathrm{~g} \mathrm{MJ}^{-1} \mathrm{~m}^{-2}$. Likely, applying $\mathrm{K}_{2} \mathrm{O}$ enhanced the LAI and this can increase RUE. Relation between LAI and RUE (Fig. 4) indicates that increasing LAI to 4.5 can raise RUE, but more LAI may cause a sharp decline in RUE.

\section{Light extinction coefficient $(K)$}

Effect of $\mathrm{K}_{2} \mathrm{O}$ on " $\mathrm{K}$ " was significant (Tab. 2). The highest value of " $K$ " was associated with 150 , and $100 \mathrm{~kg}$ ha $^{-1}$ (respectively, 0.73 and 0.71 ) that were not significantly

Tab. 2. Analysis of variance for the effects of potassium and phosphorus on the studied traits of $C$. officinalis in the field experiment

\begin{tabular}{|c|c|c|c|c|c|c|c|c|}
\hline \multirow{2}{*}{ S.O.V } & \multirow{2}{*}{ df } & \multicolumn{7}{|c|}{ Mean of squares } \\
\hline & & LIE & RUE & $\mathrm{K}$ & $\beta$-carotene & Flower dry yield & Grain yield & Biological yield \\
\hline Replication & 2 & 0.048 & 1.89 & 0.0029 & $4.32^{\circ}$ & $1421.3^{*}$ & 7208.4 & $395.1^{\circ}$ \\
\hline Phosphorus $\left(\mathrm{P}_{2} \mathrm{O}_{5}\right)$ & 3 & 57.68 & 14.19 & 0.0014 & $15.7^{*}$ & $2352.1^{*}$ & $11305.2^{*}$ & $583.2^{*}$ \\
\hline Potassium $\left(\mathrm{K}_{2} \mathrm{O}\right)$ & 3 & $202.8^{* \prime}$ & $85.13^{*}$ & $0.28^{* *}$ & $21.13^{*}$ & $2890.4^{*}$ & $9724.9^{* *}$ & $804.5^{*}$ \\
\hline $\mathrm{K}_{2} \mathrm{O} \times \mathrm{P}_{2} \mathrm{O}_{5}$ & 9 & 5.34 & 2.44 & 0.0271 & $17.19^{*}$ & $1907.3^{\prime \prime}$ & $8324.1^{*}$ & $6511.9^{*}$ \\
\hline Error & 30 & 46.53 & 16.71 & 0.0075 & 2.04 & 374.5 & 129.7 & 419.2 \\
\hline $\mathrm{CV} \%$ & & 8.31 & 9.52 & 6.27 & 2.07 & 11.31 & 9.23 & 10.13 \\
\hline
\end{tabular}

${ }^{*}$ and ${ }^{* *}$ indicating the significant differences at 5 and 1 percent probability levels 


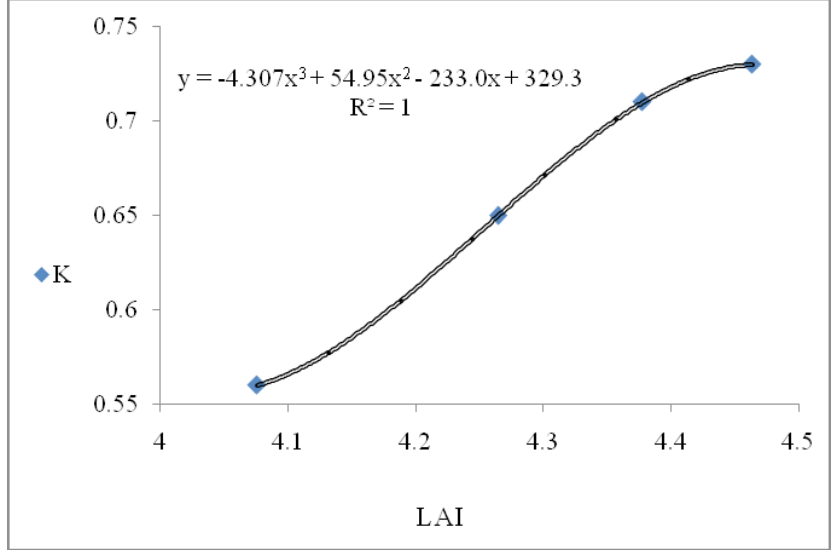

Fig. 6. Regression relation between leaf area index (LAI) and light extinction coefficient $(\mathrm{K})$ in $C$. officinalis

different (Fig. 5). $\mathrm{K}_{2} \mathrm{O}$ had positive and invigorative effect on LAI development so, light transmittance to soil surface decreased. In other words, only 27 and 29 percent of up canopy light reach to the soil surface. Fig. 6, indicates the relation between " $\mathrm{K}$ " and LAI.

Light intensity decreases from up layers of canopy to soil surface due to absorbance and reflectance of light by leaves. This reduction is described by Lambert-beer law. Accordingly, each layer with the same thickness can absorb the equal light that it transmits.

\section{Element absorption affinity $\left(k_{m}\right)$}

The highest relative growth rate (RGR) in the absence of $\mathrm{K}_{2} \mathrm{O}$, was recorded in $120 \mathrm{~kg} \mathrm{ha}^{-1} \mathrm{P}_{2} \mathrm{O}_{5}(\mathrm{RGR}=0.127)$. From Michaelis-Menten equation, the value for " $\mathrm{k}$ " in presence of $\mathrm{P}_{2} \mathrm{O}_{5}$ was $11.27 \mathrm{mg} \mathrm{g}^{-1}$, while this value in the presence of $\mathrm{K}_{2} \mathrm{O}$ was $3.48 \mathrm{mg} \mathrm{g}^{-1}$. It is concluded that pot Marigold has more affinity to $\mathrm{K}_{2} \mathrm{O}$ than $\mathrm{P}_{2} \mathrm{O}_{5}$. $" \mathrm{~K}_{\mathrm{m}}$ " is an indicator of plant growth with each unit of nutritional element, or it is the affinity of plant to absorb a specific nutrient. If plant requires an element, it will absorb that with great rate from soil solution. The higher affinity is associated with the smaller " $\mathrm{k}_{\mathrm{m}}$ " (Thomaz et al., 2007).

\section{Carotenoids}

Simple effects of $\mathrm{K}_{2} \mathrm{O}$ and $\mathrm{P}_{2} \mathrm{O}_{5}$ and their interaction were significant on petal carotenoids (Tab. 2). The highest amount of carotenoids was obtained by the application of 80 and $150 \mathrm{~kg} \mathrm{ha}^{-1} \mathrm{P}_{2} \mathrm{O}_{5}$ and $\mathrm{K}_{2} \mathrm{O}$, respectively (Tab. 3). Biochemical analysis of petals for carotenoids showed that flavenoxanthin had the highest percent then followed by luteoxanthin. $\mathrm{K}_{2} \mathrm{O}$ was more effective than $\mathrm{P}_{2} \mathrm{O}_{5}$ in carotenoids synthesis.

Borna-Nasrabadi (2006) demonstrated that mixture of NPK fertilizer increased essential oils of Silybum marianum, but higher amounts of these elements had negative effects. Naguib et al. (2005), found an increase in essential oils of pot Marigold with different micronutrients. Mandal et al. (2008) showed that potassium can increase the amount of phenols in Plantago.

\section{Dry flower yield}

Interaction between $\mathrm{P}_{2} \mathrm{O}_{5}$ and $\mathrm{K}_{2} \mathrm{O}$ on dry flower yield of pot Marigold was significant (Tab. 2). The highest yield $\left(0.16 \mathrm{~kg} \mathrm{~m}^{-2}\right)$ achieved by $120 \mathrm{~kg} \mathrm{ha}^{-1} \mathrm{P}_{2} \mathrm{O}_{5}+100$, and 150 $\mathrm{kg} \mathrm{ha}^{-1} \mathrm{~K}_{2} \mathrm{O}$ that was not different from $80 \mathrm{~kg} \mathrm{ha}^{-1} \mathrm{P}_{2} \mathrm{O}_{5}+$ 100 , and $150 \mathrm{~kg} \mathrm{ha}^{-1} \mathrm{~K}_{2} \mathrm{O}$ (Tab. 3).

Tab. 3. Comparison of means for essential oils and yield of pot marigold as affected by interaction of K and P using Duncan's multiple range test $(\mathrm{p} \leq 0.05)$

\begin{tabular}{|c|c|c|c|c|c|c|c|}
\hline $\begin{array}{c}\mathrm{P}_{2} \mathrm{O}_{5} \\
\left(\mathrm{Kg} \mathrm{ha}^{-1}\right)\end{array}$ & $\begin{array}{c}\mathrm{K}_{2} \mathrm{O} \\
\left(\mathrm{Kg} \mathrm{ha}^{-1}\right)\end{array}$ & $\begin{array}{c}\beta \text {-Carotene } \\
(\%)\end{array}$ & $\begin{array}{c}\text { Flavenoxanthine } \\
(\%)\end{array}$ & $\begin{array}{l}\text { Luteoxanthine } \\
(\%)\end{array}$ & $\begin{array}{c}\text { Grain yield } \\
\left(\mathrm{Kg} \mathrm{ha}^{-1}\right)\end{array}$ & $\begin{array}{c}\text { Flower } \\
\text { dry yield } \\
\left(\mathrm{kg} \mathrm{m}^{-2}\right)\end{array}$ & $\begin{array}{c}\text { Biological } \\
\text { yield } \\
\left(\mathrm{g} / \mathrm{m}^{-2}\right)\end{array}$ \\
\hline \multirow{4}{*}{0} & 0 & $2.5 \mathrm{~d}$ & $24.5 \mathrm{~g}$ & $12 \mathrm{~d}$ & $814 \mathrm{e}$ & 0.068 e & $360.4 \mathrm{~g}$ \\
\hline & 50 & $2.8 \mathrm{~cd}$ & $26.7 \mathrm{f}$ & $12.9 \mathrm{~cd}$ & $824 \mathrm{e}$ & $0.083 \mathrm{e}$ & $385.3 \mathrm{f}$ \\
\hline & 100 & $3.1 \mathrm{~cd}$ & $27.2 \mathrm{ef}$ & $13.3 \mathrm{~cd}$ & $942 \mathrm{~cd}$ & $0.128 \mathrm{bc}$ & $489.1 \mathrm{de}$ \\
\hline & 150 & $2.9 \mathrm{~cd}$ & $26.4 \mathrm{f}$ & $13 \mathrm{~cd}$ & $917 \mathrm{~d}$ & $0.13 \mathrm{bc}$ & $495.6 \mathrm{~cd}$ \\
\hline \multirow{4}{*}{40} & 0 & $2.6 \mathrm{~d}$ & $25 \mathrm{f}$ & $12.2 \mathrm{~d}$ & $871 \mathrm{~d}$ & $0.07 \mathrm{e}$ & $368.9 \mathrm{f}$ \\
\hline & 50 & $3.2 \mathrm{bc}$ & $27.3 \mathrm{ef}$ & $13.2 \mathrm{~cd}$ & $987 \mathrm{bc}$ & $0.089 \mathrm{~d}$ & $392.4 \mathrm{ef}$ \\
\hline & 100 & $3.4 \mathrm{bc}$ & $28.2 \mathrm{de}$ & $13.7 \mathrm{bc}$ & $974 b c$ & $0.137 b c$ & $498.3 \mathrm{~cd}$ \\
\hline & 150 & $3.9 \mathrm{~b}$ & $30.7 \mathrm{c}$ & $14.2 \mathrm{~b}$ & $1054 \mathrm{~b}$ & $0.14 \mathrm{bc}$ & $507.6 \mathrm{~cd}$ \\
\hline \multirow{4}{*}{80} & 0 & $2.7 \mathrm{~cd}$ & $26.5 \mathrm{f}$ & $13 \mathrm{~cd}$ & $982 \mathrm{bc}$ & $0.076 \mathrm{e}$ & $376.1 \mathrm{f}$ \\
\hline & 50 & $3.5 b c$ & $29.5 \mathrm{~cd}$ & $14.1 \mathrm{~b}$ & $1128 \mathrm{~b}$ & $0.095 \mathrm{~d}$ & $402.1 \mathrm{ef}$ \\
\hline & 100 & $4.1 \mathrm{~b}$ & $31.4 \mathrm{~b}$ & $14.5 \mathrm{~b}$ & $1274 \mathrm{a}$ & $0.149 \mathrm{ab}$ & $524.6 b c$ \\
\hline & 150 & $4.3 \mathrm{a}$ & $32.3 \mathrm{a}$ & $14.9 \mathrm{a}$ & $1207 \mathrm{a}$ & $0.153 \mathrm{ab}$ & $534.2 \mathrm{ab}$ \\
\hline \multirow{4}{*}{120} & 0 & $2.5 \mathrm{~d}$ & $27.2 \mathrm{ef}$ & $12.6 \mathrm{~d}$ & $852 \mathrm{~d}$ & $0.08 \mathrm{e}$ & $411.5 \mathrm{ef}$ \\
\hline & 50 & $3.5 \mathrm{bc}$ & $29.1 \mathrm{de}$ & $13.2 \mathrm{~cd}$ & $995 \mathrm{bc}$ & $0.097 \mathrm{~d}$ & $510.7 \mathrm{~cd}$ \\
\hline & 100 & $3.4 \mathrm{bc}$ & $30.2 c$ & $13.2 \mathrm{~cd}$ & $987 \mathrm{bc}$ & $0.16 \mathrm{a}$ & $548.3 \mathrm{a}$ \\
\hline & 150 & $3.4 \mathrm{bc}$ & $29.5 \mathrm{~cd}$ & $13.1 \mathrm{~cd}$ & $990 \mathrm{bc}$ & $0.161 \mathrm{a}$ & $552.1 \mathrm{a}$ \\
\hline
\end{tabular}

means with different letters in each column are different significantly at $\mathrm{p}<0.05$ 
50

\section{Conclusions}

Combination of $150 \mathrm{~kg} \mathrm{ha}^{-1} \mathrm{~K}_{2} \mathrm{O}$ and $80 \mathrm{~kg} \mathrm{ha}^{-1} \mathrm{P}_{2} \mathrm{O}_{5}$ increased petal carotenoids by $20 \%$. This can be an economic point in medicinal plants production. This result can be related to the light interception and use at the optimum fertilizer application. It is clear that $\mathrm{K}_{2} \mathrm{O}$ was effective than $\mathrm{P}_{2} \mathrm{O}_{5}$ because there was $42 \%$ increase in dry flower yield by applying $100 \mathrm{~kg} \mathrm{ha}^{-1} \mathrm{~K}_{2} \mathrm{O}$ while the highest $\mathrm{P}_{2} \mathrm{O}_{5}\left(120 \mathrm{~kg} \mathrm{ha}^{-1}\right)$ had the same effect of control.

\section{References}

Agele SO, Maraiyesa IO, Adeniji IA (2007). Effects of variety and row spacing on radiation interception, partitioning of dry matter and seed set efficiency in late season sunflower (Helianthus annus L.) in a humid zone of Nigeria. African J Agric Res 3:80-88.

Board JE, Harville BG (1992). Explanations for greater light interception in narrow vs. wide row soybean. Crop Sci 32:198-202.

Borna-Nasrabadi T (2006). Effect of different levels of nitrogen, phosphorous and potassium on fertility (growth, seed yield and essential oils) of Silybum marianum. MSc thesis. Tarbiat Modarres University, Teharan. Iran.

Gazim Z, Rezende C, Fraga S, Dias Filho B, Nakamura C, Cortez D (2008). Analysis of the essential oils from Calendula officinalis growing in Brazil using three different extraction procedures. Brazilian Journal of Pharmaceutical Sciences 44(3):391-395.

Everet PH, Subramanya R (1983). Pepper production as influenced by plant spacing and nitrogen-potassium rates. Proc Fla State Hort Soc 96:79-82.

Hoeft RG, Nafziger ED, Johnson RR, Aldrich R (2000). Modern corn and soybean production, MCSP Publications, USA, p. 353.

Jones JB, Stanley CD, Csizinszky AA, Kovach SP, McGuire RG (1988). K and $N$ fertilization rated influence susceptibility of trickle-irrigated tomato plants to bacterial spot. HortScience 23(6):1013-1015.
Mandal K, Saravanan R, Maiti S (2008). Effect of different levels of N, P and $\mathrm{K}$ on downy mildew (Peronospora plantaginis) and seed yield of isabgol (Plantago ovata). Crop Prot 27(6):988-995.

Mrda J, Marinković B, Jaćimović G (2007). Effect of row spacing on calendula (Calendula officinalis L.) flowers production. International Symposium "Trends in European Agriculture Development", Scientific Papers Faculty of Agriculture 39(1):77-82.

Naguib NY, Khalil MY, El Sherbeny SE (2005). A comparative study on the productivity and chemical constituents of various sources and species of Calendula plants as affected by two foliar fertilizers. Journal of Applied Sciences Research 1(2):176-189.

Purcell LC, Ball RA, Reaper JD, Vories ED (2002). Radiation use efficiency and biomass production in soybean at different plant population densities. Crop Sci 42:172-177.

Rosenthal WD, Gerik TJ, Wade LJ (1993). Radiation use efficiency among grain sorghum cultivars and plant densities. Agron J 85(3):703-705.

Taiz L, Zeiger E (2003). Plant physiology. ( $3^{\text {rd }}$ Ed). Sinauer associates p. 623.

Thomaz S, Chambers PA, Pierini S, Pereire G (2007). Effect of phosphorus and nitrogen amendments on the Growth of Egeria najas. Aquatic Botany 86:191-196.

Varban D, Marcel M, Varban R, Muntean S (2008). The influence of the nutrition space upon the production at Calendula officinalis L. specie, in the condition of ClujNapoca. Scientific Papers Faculty of Agriculture 40(1):235238.

Vijay N, Kumar A, Bhoite A (2009). Influence of Nitrogen, Phosphorus and Potassium Fertilizer on Biochemical Contents of Asparagus recemosus (Willd.) Root Tubers. Research Journal of Environmental Science 3(3):285-291. 